\section{O FUTURO PERFEITO}

De John Micklethwait e Adrian Wooldridge

Rio de Janeiro : Campus, 2001. 419 p.

Por Marcos Fernandes, Professor do Departamento

de Planejamento e Análise Econômica Aplicados

à Administração da FGV-EAESP.

E-mail: mdasilva@fgvsp.br

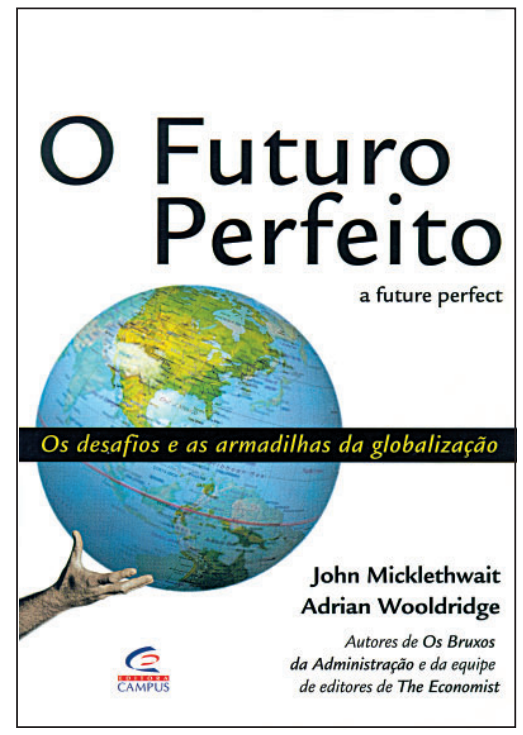

defesa da globalização. Esse livro surge num momento em que a ausência de razão crítica e de pragmatismo, no que se refere ao ataque e a algumas defesas da globalização, parece imperar.

Os acontecimentos no ano passado em Gênova revelam-nos que, no mínimo, sejamos a favor ou contra a globalização, devemos debater esse tema com mais cautela ou, precisamente, com a busca da razão, não da escuridão dos dogmas, do maniqueísmo fácil e da demonização dos fatos.

Afinal, o que é globalização? Essa questão é sabiamente discutida pelos autores logo no início do livro; sabiamente, digo, pois, aparentemente, ninguém sabe o que vem a ser isso e, ao mesmo tempo, todo o mundo só fala em globalização, seus custos e benefícios, suas consequiências para o crescimento e desenvolvimento globais, sobre o meio ambiente e por aí vai.

Analisando friamente os fatos, é difícil definir globalização como a intensificação dos fluxos de comércio e de capital. Sabemos que tal processo, se definido como expansão mundial do comércio, realmente se intensifica a partir do século XVI. Os trabalhos de Fernand Braudel mostram, com clareza e erudição ímpares, a magnitude e profundidade das mudanças econômicas, sociais e políticas engendradas por esse processo que é, diga-se de passagem, secular. No entanto, sabemos que os analistas e o público, quando se referem à globalização, estão a considerar o processo de liberalização - relativa - do comércio e dos fluxos de capitais ocorrido principalmente a partir dos anos 90 do século passado. 
A bem da verdade, há um aumento do comércio e uma queda relativa das barreiras comerciais, assim como uma migração de capitais para países emergentes, característica peculiar da era Clinton. Todavia, a globalização, aparentemente, afeta mais intensivamente a vida dos países hoje já considerados ricos e de renda per capita alta. Por mais que tenha migrado o capital para países emergentes, mote, aliás, inventado durante esse período de alegada globalização sabe-se lá do que e para quem, os fluxos ainda são irrisórios se comparados com aqueles que ocorrem entre as economias mais ricas do mundo.

Por essa e outras razões, fica realmente difícil definir globalização. Talvez a melhor forma de dar um sentido razoável a tal conceito seja - para o agrado daqueles que defendem e atacam a globalização - defini-la como a expansão do capitalismo, do mercado e de suas relações em nível mundial.

É essa visão de globalização a adotada, corretamente no meu entender, pelos autores. Neste sentido, as grandes questões, os prós e contras, afloram com maior clareza. $\mathrm{Na}$ verdade, do ponto de vista do livro, a globalização vista dessa forma pode trazer benefícios para as economias do mundo - exceção talvez ao velho drama africano - devido à expansão do capitalismo e da prosperidade.

Com a definição de globalização, torna-se realmente mais fácil o entendimento do debate em torno dela. A esquerda, em maior ou menor grau, tende a ver negativamente a globalização, pois ela traduz-se, em última instância, como a expansão do capitalismo capitaneado pela única potência realmente hegemônica hoje, a qual dispensa apresentação.

A questão que se coloca é se realmente isso representa um problema. O livro defende a globalização, uma vez que ela permite que o sonho de um mundo sem fronteiras seja realmente factível, e isso somente seria possível imaginando-se algo como um mundo federativo. Esquecemse, porém, os autores que tal utopia somente se realizará, de verdade, com o livre fluxo de bens, capitais e pessoas, algo que, infelizmente, ainda esbarra em barreiras políticas, ideológicas e valorativas. Sem isso, de fato, a globalização pode transformar-se somente na expansão do capitalismo em um só país, para usar a analogia do debate da velha Internacional. Aliás, os autores são coerentes com esse ponto de vista ao analisarem a teimosa resistência dos estados nacionais.

Uma grande virtude do livro é desmitificar o debate com dados e fatos, algo também raro quando o tema é globalização. Característica marcante daqueles guiados pela razão crítica e pragmatismo, não se aceita, nesse livro, possibilidade de se fazerem afirmações sobre o intangível ou sobre as lógicas metafísicas e conspiratórias reificantes do Capital (sempre com $C$ maiúsculo!).
Um tema que não é abordado no livro, dada sua própria proposta, mas que suscita debates e inquietações, é o impacto multidimensional da globalização, isto é, sua importância não somente econômica, mas cultural (multicultural?), subjetiva. Adicionalmente, deveria haver maior discussão sobre os limites do mercado, principalmente no que se refere ao problema da democracia. A expansão do consumo, a inclusão - se vier a ocorrer - de grandes contingentes de consumidores, garante apenas a possibilidade de existência de escolhas privadas, mas não públicas. As escolhas dos consumidores são privadas; a liberdade de escolha de produtos também é privada. No entanto, a liberdade no sentido mais amplo do termo constitui-se numa escolha pública calcada na democracia, pelo menos do ponto de vista normativo.

A democracia não se confunde com a liberdade de escolha para se consumir hambúrgueres; ela está muito, muito, além disso. Note: somente $25 \%$ dos eleitores estadunidenses elegem um presidente; ao que tudo indica, aparentemente, passa a ser um valor somente o business, deixando-se de lado, naquele país, aspectos relevantes relacionados ao espaço público e à escolha pública. Será que o modelo global será também o do puro consumismo, em que se confunde democracia com hambúrgueres de diferentes qualidades disponíveis para o consumo?

Há uma anulação, perigosa no meu entender, do espaço público em detrimento somente das escolhas privadas, como se a cidadania se resumisse à possibilidade de se consumir. Este é um dos grandes perigos - esse sim - da globalização entendida somente como a expansão dos "EUA Corporation".

Outro ponto importante, mas mais controverso no meu entender, é o impacto da cultura pop norte-americana sobre a diversidade cultural do mundo. No entanto, o risco de se adotarem posições reacionárias é muito grande quando se aborda esse tema. Não é razoável supor que ficaremos isolados da influência cultural dos EUA. Nem os descendentes de Vercingetorix (e de Asterix e Obelix) conseguiram escapar da hegemonia da cultura romana. Tampouco a cultura romana escapou ilesa da influência de seus dominados. O ponto é: qual será a capacidade de assimilação, mantendo-se a diversidade, por parte da cultura pop estadunidense, dos mais diversos "olhares" e percepções subjetivas que constituem as mais diferenciadas visões de mundo.

De uma forma ou de outra, seja você a favor ou contra, ou que não tenha nenhuma opinião a respeito, estejam os autores corretos na utopia, sejam eles talvez ingênuos nas conseqüências dela, não importa, o fato é que Um futuro perfeito instiga-nos a reflexões de qualidade sobre um fenômeno que pouco dominamos e realmente compreendemos. $\bigcirc$ 